\title{
Antosiyanince Zengin Kiraz Grubu Meyvelerin İnsan Sağlı̆̆ı Üzerine Etkilerini İnceleyen Klinik Çalışmalara Bir Bakış
}

\author{
Hatice Merve BAYRAM ${ }^{*}$, Arda ÖZTÜRKCAN**
}

$\ddot{O} \mathbf{z}$

Antosiyanince zengin kiraz grubu kırmızı meyveler, düşük kalorili olmalarının yanı sıra lif, C vitamini, polifenoller, karotenoidler ve potasyum gibi bazı mineraller dahil olmak üzere yüksek miktarda biyoaktif bileşene sahiptir ve bu nedenle antioksidan kapasiteleri yüksektir. Türkiye toplam meyve üretiminde dünyada dördüncü, kiraz üretiminde birinci ve vişne üretiminde üçüncü sırada yer almaktadır. Üretimi oldukça yüksek olan ve sağlı̆̆ı olumlu yönde etkileyerek diyabet, kardiyovasküler hastalıklar, hipertansiyon, obezite ve yağlı karaciğer hastalığı gibi hastalıkların risklerini ve semptomlarını azalttığı düşünülen bu meyvelere olan ilginin ülkemizde arttırılması önemlidir. Bu derlemenin amacı, ülkemizde yetiştiriciliği yüksek ve dünya sıralamasında önemli bir yerde olan, doğada doğal olarak bulunan en güçlü antioksidan bileşik olan antosiyanince zengin kiraz grubundan olan kiraz, vişne ve kızılcık kırmızı meyvelerinin insan sağllğı üzerine etkilerini inceleyen klinik çalışmaları değerlendirmektir. Bu amaçla Dergipark, PubMed ve Google Scholar veri tabanlarında literatür taraması yapılmış ve kiraz grubu kırmızı meyvelerin insan sağllğı üzerine etkinliğini değerlendiren toplam 27 uluslararası klinik çalışma derlemeye dahil edilmiştir. Türkiye'de yapılmış bir klinik çalışmaya rastlanmamıştır. Sonuçlar, kiraz grubu kırmızı meyvelerin antioksidan, anti-inflamatuar, anti diyabetik, hipolipidemik, hipertansiyon ve kardiyovasküler sistemi koruyucu etkileri ve uyku ile ruh hali üzerinde olumlu

\footnotetext{
Derleme Makale (Review Article)

Geliş / Received: 05.06.2020 \& Kabul / Accepted: 30.06.2020

DOI: https://doi.org/10.38079/igusabder.748640

${ }^{*}$ Arş. Gör., İstanbul Gelişim Üniversitesi, Sağlık Bilimleri Yüksekokulu, Beslenme ve Diyetetik Bölümü, İstanbul, Türkiye. E-posta: hmbayram@gelisim.edu.tr ORCID https://orcid.org/oooo0002-7073-2907

*** Doç. Dr., İstanbul Gelişim Üniversitesi, Sağllk Bilimleri Yüksekokulu, Beslenme ve Diyetetik Bölümü, İstanbul, Türkiye, E-posta: turkcana@hotmail.com ORCID https://orcid.org/oooo$\underline{0001-7982-6988}$
} 
etkileri olabileceğini göstermektedir fakat etkisi saptanmayan çalışmalarda mevcuttur. Güncel çalışmalar kiraz grubu kırmızı meyvelerin sağlığı olumlu yönde etkileyeceği konusunda oldukça umut verici olsa da kesin mekanizmalarının ve sonuçlarının aydınlatılabilmesi adına insanlar üzerinde yapılacak daha fazla klinik çalışmaya ihtiyaç vardır.

Anahtar Kelimeler: Kırmızı meyveler, kiraz, vişne, kızılcık, sağlık etkisi

\title{
Investigating the Effects of Anthocyanin Rich Cherry Red Fruits on Human Health in Clinical Studies
}

\begin{abstract}
Anthocyanin-rich cherry red fruits contain lower calories and high antioxidant capacities due to their high content of bioactive components, including fiber, vitamin C, polyphenols, carotenoids and some minerals such as potassium. Turkey ranks fourth in total fruit production, which ranks first in laurel cherry production and third in sour cherry production in the world. It is important to increase the interest in these fruits, which are very high in production and which are thought to reduce the risks and symptoms of diseases such as diabetes, cardiovascular diseases, hypertension, obesity and fatty liver disease by affecting health positively. The aim of this review is to evaluate the effects of sour cherry, tart cherry and cornelian cherry fruits on human health, which are the most powerful antioxidant compounds naturally found in red fruits, anthocyanin rich cherry group, and highly cultivated in our country and important in the world ranking. For this aim, a literature review was conducted in Dergipark, PubMed and Google Scholar databases and 27 international clinical studies evaluating the effects of cherry group red fruits on human health were included in the review. It was observed there was no clinical study conducted in Turkey. The results show that cherry group red fruits may have antioxidant, anti-inflammatory, anti-diabetic, hypolipidemic, hypertensive and protective effects on the cardiovascular system and positive effects on sleep and mood. Although current studies are very promising that anthocyanin-rich cherry group fruits will positively effect health, more clinical studies are needed on humans in order to clarify their exact mechanisms and results.
\end{abstract}

Keywords: Red fruits, sour cherry, tart cherry, cornelian cherry, health effect.

\section{Giriş}

Eski yllardan beri bitkilerin tedavi edici özellikleri kullanılmakta olup, popülerliği günümüzde hala yerini korumaktadır ve bu alana olan ilgi giderek artmaktadır ${ }^{1}$. Dünya Sağlık Örgütü (DSÖ)'nün 2011 yllındaki raporunda, gelişmekte olan ülkelerin bitkisel ilaç kullanım oranlarının \%65 ile \%80 arasında değiştiğini açılanmıştı² ${ }^{2}$ Bu nedenle DSÖ, 
1999 ile 2010 yılında seçilmiş bitkilerin 5 ciltlik monografilerini yayınlamış ve tıbbi yararları olan bitki türleri ile bunların doğru şekilde kullanımları konusunda bilgi vermeyi amaçlamıştır ${ }^{3}$. 2019 yılında yayınladığı son raporunda ise 110 ülkenin tedavi amacıyla bitkileri ve 93 ülkenin bu konuda monografileri kullandıklarını rapor etmiştir4 . Literatürde ülkemizde, DSÖ’nün raporu dışında da tedavi edici olarak bitkilerin kullanım sıklığını değerlendiren çalışmalara rastlanmıştır. Ancak, bu çalışmaların bölgesel çalışmalar olup, o bölgeye özgü tedavi edici olarak kullanılan bitkileri

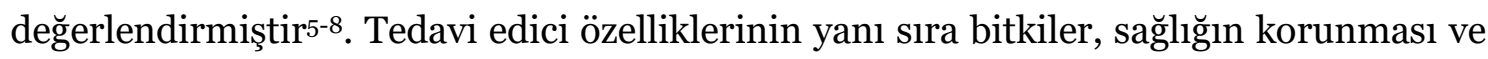
devamlılı̆̆ içinde oldukça önemlidir

Epidemiyolojik çalışmalar, kronik inflamatuar hastalıklar ile meyve ve sebze alımı arasında ters bir ilişki olduğunu göstermektedir ${ }^{9,10}$. Meyve ve sebze tüketiminin, kardiyovasküler hastalık (KVH), inme, Diabetes Mellitus (DM), Metabolik Sendrom, Non-alkolik yağlı karaciğer hastalığı ve bazı kanserlerden kaynaklanan tüm nedenlere bağlı mortalite ve morbidite risklerini azalttı̆̆ını bildirilmiştir ${ }^{10-13}$. Meyvelerin bu etkinliklerini içerdikleri vitaminler, mineraller, karotenoidler ve lifin yanı sıra sekonder metabolitlerle gerçekleştirdiklerine inanılmaktadır ${ }^{10}$.

Sekonder metabolitler olarak adlandırılan fenolik bileşikler temelde; antosiyaninler, iridoidler, fenolik asitler, tanninler ve flavonoidler olarak beş gruptan oluşmaktadır ${ }^{14}$. Fenolik bileşiklerin toksisiteleri henüz belirlenmemiş olup, incelenen çalışmalarda toksik etkisine rastlanmamıştır15-17.

Antosiyaninler, birçok bitki dokusunun mavi, mor ve kırmızı renginden sorumlu suda çözünür bitki metabolitleridir. $\mathrm{Bu}$ nedenle kırmızı meyveler rengini aldıkları antosiyanini bol miktarda bulundururlar. Kırmızı meyveler, zengin antioksidan gıdalar olarak, son yıllarda tüketiciler ve üreticiler için önem kazanmıştır ${ }^{18}$.

Kırmızı meyveler botanik olarak üzümsü meyveler (berry fruits) ve kiraz grubu meyveleri (cherry fruits) olarak 2 grupta incelenebilir ${ }^{18}$. Kırmızı meyveler, diğer meyvelere göre nispeten düşük kalorili olup, lif, C vitamini, polifenoller, karotenoidler ve potasyum gibi bazı mineraller dahil olmak üzere yüksek miktarda biyoaktif bileşene sahip yoğun meyvelerdir ${ }^{10}$.

Türkiye meyve yetiştiriciliğinde dünyada dördüncü sırada olarak oldukça önemli bir yere sahiptir ve meyve üretim miktarı gün geçtikçe artmaktadır. 2019 Türkiye İstatistik 
Kurumu (TÜİK) verilerine göre bu değer 20,578,453 tondur. Ayrıca 664,224 tonluk kiraz üretimi ile dünyada birinci sırada yer alıp, \%26’sını ihraç etmektedir. Bunun yanı sıra, 182,165 tonluk vişne üretimi ile de dünyada üçüncü sırada yer almaktadır. Diğer kiraz grubu bir meyve olan kızlcık üretimi ise 10,269 tondur ${ }^{19}$. Bu derlemenin amacı ülkemizde yetiştiriciliği yüksek ve dünya sıralamasında önemli bir yerde olan, doğada doğal olarak bulunan en güçlü antioksidan bileşik olan antosiyanince zengin kiraz grubundan olan kiraz, vişne ve kızılcık kırmızı meyvelerinin insan sağlığı üzerine etkilerini inceleyen çalışmaları değerlendirmektir.

Kiraz grubu kırmızı meyvelerin insan sağlı̆̆ı üzerine etkilerini değerlendirmek amacıyla Dergipark, PubMed ve Google Scholar veri tabanlarında literatür taraması yapılmış ve bu konu ile ilgili toplam 27 uluslararası çalışma derlemeye dahil edilmiştir. Türkiye’de yapılmış bir klinik çalışmaya rastlanmamıştır.

\section{Kiraz Grubu Kırmızı Meyvelerinin Biyoaktif Bileşenleri}

Botanik olarak kiraz grubu meyveleri sert çekirdekli meyveler olarak tanımlanır. Genellikle sofralık meyve olarak tüketilmesinin yanı sıra, ticari olarak besin sanayisinde yaygın olarak kullanılmaktadır ${ }^{20}$. 100'den fazla kiraz grubu meyve çeşidi olmakla birlikte, temel olarak kiraz ve vişne olarak 2'ye ayrılırlar ${ }^{10}$. Kiraz, Prunus avium L., ve vişne, Prunus cerasus, Rosales takımının, Rosaceae familyasının, Prunoideae alt familyasının, Prunus cinsi içerisinde yer alır ${ }^{20}$. Ülkemizde yetiştirilen diğer kiraz grubu bir meyve olan kızılcık, Cornus Mas L., ise Cornaceae familyasına Cornales alt familyasının Cornus cinsine ait bir meyve türüdür²1

\section{Fenolik bileşikler}

Kiraz grubu kırmızı meyveler yüksek oranda fenolik bileşik içermektedir. Fenolik bileşikler meyvenin çeşidi, yetiştirildiği yer, yetiştirilme şekli, olgunluğu, hasat zamanı, depolama koşulları gibi birçok faktöre bağlı olarak değişkenlik göstermektedir ${ }^{22}$.

Yüksek antosiyanin ve hidroksisinamik asit nedeniyle vişne, kiraza göre göre daha yüksek oranda fenolik bileşik değerine sahiptir ${ }^{23}$. Türkiye'de yapılan çalışmalarda kirazların toplam fenolik bileşikleri 47,75 mg gallik asit eşdeğeri (GAE)/100g ile 3254,2

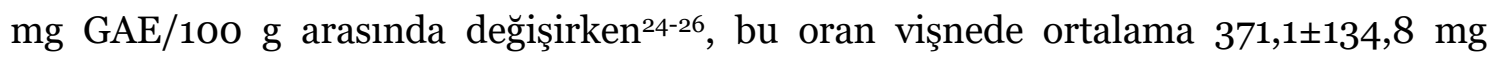
GAE/100 g25 ve kızllcıkta 19,80 mg GAE/100g ile 5114,5 mg GAE/100 g arasında ölçülmüştür $25,27,28$. 


\section{Antosiyaninler}

Antosiyaninler meyvelere ait kırmızı, mavi ve mor renkten sorumlu bileşenler olup kiraz grubu kırmızı meyvelerde yüksek miktarlarda bulunurlar ${ }^{10}$. Meyvenin rengindeki değişiklikler olgunlaşma sırasında antosiyanin birikimi ile pozitif korelasyon gösterir ${ }^{23}$. Baskın antosiyanin grupları, kirazda siyanidin-3-glukozit, vişnede siyanidin 3rutinositito,20, kızılcıkta ise siyanidin rutinosit ve pelargonidin galaktosittir ${ }^{21}$.

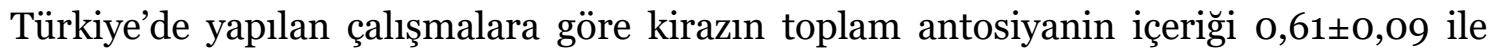
29,09 $\pm 1,01 \mathrm{mg}$ siyanidin-3-rutinosit eşdeğeri (CRE)/100 g g $^{24,26}$, vişnenin 14,54 $\pm 8,21$ ile $62,39 \pm 48,25 \mathrm{mg} / 100 \mathrm{~g}$ arasında değişmektedir 29,30. Kızılcığın antosiyanin değeri $229 \pm 16,9$ mg epigallokateşin gallat eşdeğeri (EGCC-E)/g olarak ölçülmüştür²7.

\section{Fenolik Asitler}

Fenolik asitler hidroksisinamik ve hidroksibenzoik asitler olmak üzere iki gruba ayrılırlar. Hidroksibenzoik asitler bitkilerde genellikle eser miktarda bulunurlar ${ }^{22}$. Kiraz ve vişne de ana fenolikler hidroksisinamik asit olup türevleri neoklorojenik, caffeoilkinik, p-koumaroilkinik ve klorojenik asitlerdir. Neoklonorejik asidin p-koumaroilkinik aside oranı kiraz grubu meyvelerde ekşi tatlarından sorumlu ana bileşenlerdir ${ }^{23}$. Hidroksisinamik asit değeri kirazda 27,23 mg/100 g ile 93,22 mg/10o g arasında olup Türkiye'de yetiştirilen vişne ve kızılcık meyveleri için bir değere rastlanmamıştır3'

\section{Flavonoid ve flavanoller}

Kiraz ve vişne flavonoidleri ağırlıklı olarak kaempferol 3-rutinosit, kuersetin 3-rutinosit ve kuersetin 3-glukozitten oluşmaktadır. Flavanoller (kateşin, epikateşin ve polimerik prosiyanidin) genotipe bağlı olarak farklı oranlarda bulunurlar²3. Kızılcıkta da epikateşin en bol bulunan flavanol olup ${ }^{32}$ kateşin, proantosiyanin içerirken32,33 kuarsetin 3glukuronit, kuersetin 3-glukozit, kuersetin 3-ramnoz yaygın olarak bulunan flavonoid gruplarıdır34-36.

Yukarıda bahsedilen biyoaktif bileşenler dışında, yüksek oranda C vitamini içermekte olan bu gruptaki meyveler, $\beta$ karoten, A vitamini, E vitamini ile potasyum başta olmak üzere mineral açısından da oldukça zenginlerdir ${ }^{23,36,37}$. Tablo 1, kiraz grubu kırmızı meyvelerin enerji ve besin ögesi değerleri ile Türkiye'de yetiştirilen bu meyvelerin toplam fenolik bileşik, antosiyanin ve flavonoid miktarlarını göstermektedir. 
Tablo 1. Kiraz grubu kırmızı meyvelerin enerji ve besin ögesi değerleri ile Türkiye’de yetiştirilen kiraz gurubu meyvelerinin toplam fenolik bileşik, antosiyanin ve flavonoid miktarları

\begin{tabular}{|c|c|c|c|}
\hline & Kiraz & Vişne & Kizılcık \\
\hline Enerji (kkal)* & 63 & 66 & 64 \\
\hline $\begin{array}{l}\text { Karbonhidrat } \\
\text { (g)* }\end{array}$ & 16,01 & 12,8 & 12,87 \\
\hline Protein (g)* & 1,06 & 0,64 & 0,28 \\
\hline Yăg (g)* & 0,2 & 0,49 & 0,42 \\
\hline Lif $(g)^{*}$ & 2,1 & 3,4 & 3,71 \\
\hline $\begin{array}{l}\text { C vitamini } \\
\text { (mg)* }\end{array}$ & 7 & 10 & 66,2 \\
\hline \multirow{3}{*}{$\begin{array}{l}\text { Toplam } \\
\text { fenolik bileşik }\end{array}$} & $265 \pm 8,6 \mathrm{mg} \mathrm{GAE} / 100 \mathrm{~g}^{24}$ & $371,1 \pm 134,8 \mathrm{mg} \mathrm{GAE} / 100 \mathrm{~g}^{25}$ & $4918,8 \pm 195,7 \mathrm{mg} \mathrm{GAE} / 100 \mathrm{~g}^{25}$ \\
\hline & $3129,2 \pm 125 \mathrm{mg} \mathrm{GAE} / 100 \mathrm{~g}^{25}$ & $14,23 \pm 0,38 \mathrm{mg} / \mathrm{g}^{29}$ & $31,25 \pm 1,79$ mg GAE/g27 \\
\hline & $\begin{array}{l}58,31 \pm 10,56 \text { ile } 115,41 \pm 7,98 \\
\text { mg GAE/ } 100 \text { g }^{26}\end{array}$ & & $19,87 \pm 0,27 \mathrm{mg} \mathrm{GAE} / \mathrm{g}^{28}$ \\
\hline \multirow{2}{*}{$\begin{array}{l}\text { Toplam } \\
\text { antosiyanin }\end{array}$} & $65 \pm 4,2 \mathrm{mg} / 100 \mathrm{~g}^{24}$ & $0,41 \pm 0,02 \mathrm{mg} / \mathrm{g} 33$ & $229 \pm 16,9$ mg EGCC-E/g27 \\
\hline & 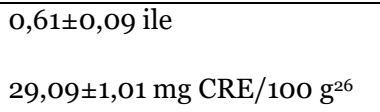 & $\begin{array}{l}14,54 \pm 8,21 \text { ile } \\
62,39 \pm 48,25 \mathrm{mg} / 100 \mathrm{~g}^{30}\end{array}$ & \\
\hline \multirow{2}{*}{$\begin{array}{l}\text { Toplam } \\
\text { flavonoid }\end{array}$} & $952,5 \pm 47,6 \mathrm{mg}(+) \mathrm{CE} / 100 \mathrm{~g}^{25}$ & $420,5 \pm 21,1 \mathrm{mg}(+) \mathrm{CE} / 100 \mathrm{~g}^{25}$ & $477,3 \pm 22,9 \mathrm{mg}(+) \mathrm{CE} / 100 \mathrm{~g}^{25}$ \\
\hline & & & $0,59 \pm 0,01 \mathrm{mg} \mathrm{QE} / \mathrm{g}^{28}$ \\
\hline
\end{tabular}

* Enerji ve besin ögesi değerleri BeBİs bilgisayar programı ile hesaplanmıştır, GAE: gallik asit eşdeğeri, EGCC-E: epigallokateşin gallat eşdeğeri, CRE: siyanidin-3-rutinosit eşdeğeri, CE: kateşin eşdeğeri, QE: kuarsetin eşdeğeri

\section{Kiraz grubu kırmızı meyvelerin sağlık üzerine etkileri}

Kiraz grubu kırmızı meyvelerin yüksek oranda içerdikleri biyoaktif bileşenler (örn., antosiyaninler, hidroksisinamik asitler, flavanoller vb.) göz önüne alındı̆̆ında, tüketimlerinin sağlı̆̆ı desteklemesi ile hastalıklara yakalanma riskleri ve semptomlarını azaltmaları şaşırtıcı değildirio. 


\section{Antioksidan etkisi}

Meyvelerin antioksidan kapasitesi, içerdikleri biyoaktif bileşenler ile reaktif oksijen türlerini (ROS) temizleme kapasiteleri seviyeleriyle pozitif ilişkilidir ${ }^{8}$. Antosiyanince zengin kırmızı meyvelerin tüketimi ile birlikte KVH, kanser ve inflamatuar süreçler dahil olmak üzere ROS’un neden olduğu bozuklukların azalabileceği düşünülmektedir ${ }^{17}$. Jacob ve ark.,39 2003 yılında yaptıkları çalışmada sağlıklı 10 kadına iki servis halinde akşam yemeğinden sonra $280 \mathrm{~g}$ kiraz takviyesinin plazma ürat seviyesini 5 saat sonra azalttığını gözlemlemişlerdir. Plazma C-reaktif protein (CRP), nitrit oksit (NO) seviyeleri ise 3 saat sonra azalma göstermiş fakat albümin ve tümör nekroz faktör (TNF- $\alpha$ ) seviyeleri değişmemiştir. Traustadottir ve ark., ${ }^{40} 2009$ yılında sağlıklı 12 yaşlı bireye 14 gün boyunca günde $240 \mathrm{ml}$ vişne suyu takviyesinin serumda F2 isoprostan ve idrarda 8hidroksiguanosidi azalttığı gözlemlemişlerdir. Bu biyobelirteçler özellikle özafagus adenokarsinomu ile ilgili olup41, bulunan sonuçlar, kiraz grubu kırmızı meyvelerin antioksidan kapasiteyi artırabileceğini ve oksidatif hasarı azaltabileceğini düşündürmektedir. Yine, Lynn ve ark., ${ }^{42} 2014$ yılındaki çalışmalarında da sağlıklı 47 yetişkin bireye 6 hafta $30 \mathrm{ml} /$ gün konsantre vişne suyu takviyesinin plazma antioksidan seviyelerini artırdığını rapor etmişlerdir.

\section{Anti-inflamatuar etkisi}

Artan oksidatif stres ve iltihaplanma, tip 2 Diabetes Mellitus (T2DM), KVH ve kanser dahil olmak üzere kronik inflamatuar hastalıkların ana nedenleri arasındadır43. Kiraz grubu kırmızı meyvelerin anti-inflamatuar etkinlikleri yapılan klinik çalışmalarda belirlenmiştir.

Kelley ve ark.,43 2013 yılında yaptıkları bir çalışmada sağlıklı 18 yetişkin bireye 28 gün diyet karbonhidratlarının yerine 280 g kiraz takviyesinin, CRP'yi \%20,1, IL-18’i \%8,1, ileri glikasyon son ürünlerini (AGE) \%29, plazminojen aktivatör inhibitör-1’i \%19,9, endotelin-1 (ET-1)'i \%13,7 ferritini \%20,3 oranında azalttığını ve IL-1’i \%27,9 oranında arttırdığını gözlemlemişlerdir. Martin ve ark.,44 2019 yılında yaptıkları çalışmalarında hafif kilolu ve obez 26 bireyde 4 hafta $240 \mathrm{ml}$ vişne suyu takviyesinin, serum ürat seviyesini \%19,2, CRP’yi \%19,4 ve monosit kemoatraktan protein-1’i \%6,3 azalttı̆̆ını saptamıştır. Farklı olarak, Bell ve ark., 452014 yılında sağlıklı 12 yetişkin bireye 10 gün boyunca 30 ya da $60 \mathrm{ml}$ konsantre vişne suyu takviyesi sonrası, $60 \mathrm{ml}$ vişne suyunun 3 
saat sonra CRP ve ürik asit seviyelerinde azalma gösterse, 8 saat sonra ürik asit seviyeleri artarak başlangıç düzeyine ulaştığını saptamışlardır.

Literatürde sporcular üzerinde kiraz grubu kırmızı meyvelerin antioksidan ve antiinflamatuar etkileri sıklıkla çalışılmıştır. Howatson ve ark., ${ }^{46} 2010$ yılında yaptıkları bir çalışmada maraton koşucusu 20 bireye egzersizden 5 gün önce ve 2 gün sonra $240 \mathrm{ml}$ vişne suyu takviyesinin egzersizle ilişkili artan CRP, IL-6 ile kas hasarı ve ağrısını azalttığını göstermişlerdir. Bell ve ark.,47 2014 yılında bisiklet sürme egzersizi yapan 16 bireye egzersiz sonrası 5., 6. ve 7. günlerde $30 \mathrm{ml}$ konsantre vişne suyu takviyesi yaptıkları çalışmalarında vişne suyu takviyesinin, serum CRP, IL-6 ve lipid hidroperoksitlerini azalttığını bulmuşlardır. Levers ve ark.,48 2015 yılında direnç egzersizi yapan 23 erkeğe, egzersizden 2 gün önce başlanacak şekilde toplam 10 gün boyunca 480 mg vişne içeren kapsül takviyesinin, serum antioksidan biyobelirteçlerinde bir değişikliğe neden olmadığını fakat egzersiz sonrası kas ağrılarını azalttı̆̆ını ve egzersizden 48 saat sonra Aspartat transaminaz (AST), Alanin aminotransferaz (ALT) ve kreatinin seviyelerinde azalmaya yol açtığını tespit etmişlerdir. 2016 yılındaki diğer çalışmalarında ise dayanıklılık egzersizi yapan 27 atlet ve koşucuya 10 gün boyunca kapsül halinde $480 \mathrm{mg}$ vişne takviyesi, maraton süresinde iyileşmeye ve kas katabolizmasına ait (kreatinin, total protein ve kortizol) oksidatif stres biyobelirteçlerinde azalmaya, idrar ürat seviyeleri ile toplam serum antioksidan kapasitesinde artışına yol açmıştır ${ }^{49}$. Tersine, McCormick ve ark.,50 2016 yılında su topu oyuncusu 9 erkekte yaptıkları çalışmalarında, 6 gün $90 \mathrm{ml}$ konsantre vişne suyu takviyesinin, serum antioksidan ya da inflamatuar belirteçlerinde önemli bir etki göstermediğini, performans sonrası yenilenmede etkili olmadığını saptamışlardır.

\section{Diyabet ve lipid metabolizması üzerine etkisi}

DM prevalansı gün geçtikçe hem ülkemizde hem de dünyada artmaktadır ve glisemik kontrol hastalık için en önemli tedavi yöntemidir51. DM lipid metabolizmasında bozulmalara tek başına yol açabildiği gibi lipid metabolizmasında DM'den bağımsız bozukluklarda meydana gelebilmekte ve bu durum özellikle kardiyovasküler ve serebrovasküler hastalıklarla ilişkili bulunmaktadır ${ }^{16,52}$. Dislipideminin vasküler bütünlüğü, yapısını ve fonksiyonunu bozabileceği gösterilmiştir ${ }^{16}$. Kiraz grubu kırmızı meyvelerin yüksek antioksidan ve anti-inflamatuar etkilerinden dolayı DM hastalığı ve lipid bozukluklarını iyileştirmede etkin oldukları düşünülmektedir ${ }^{16,53-55}$. 
Ataie-Jafari ve ark., 532008 yılındaki çalışmalarında T2DM hastası olan 19 kadın bireyde 6 hafta $400 \mathrm{ml}$ vişne suyu takviyesinin açlık kan şekerini \%8 oranında; vücut ağırlığı, kan basıncı, hemoglobin A1c (HbA1c), total kolesterol (TC) ve yüksek yoğunluklu lipoprotein (LDL) seviyelerinde azalmaya yol açtığını göstermişlerdir. Soltani ve ark.,54 2015 yılında T2DM'li 60 yetişkin bireyde 6 hafta $300 \mathrm{mg}$ kızılcıktan izole edilmiş antosiyanin içeren kapsülün günde 2 kez takviyesinin insülin seviyelerinde artış, HbA1c ve TG seviyelerinde azalmaya yol açtığını göstermişlerdir. Asgary ve ark., ${ }^{16} 2013$ yılında yaptıkları bir çalışmada dislipidemik 40 çocuk ve adölesanda 6 hafta günde 2 kez 50 g kızılcık takviyesinin, TC, TG, LDL, apolipoprotein B (Apo B), hücre içi adezyon molekülü-1 (ICAM-1) ve vasküler hücre adezyon molekülü 1 (VCAM-1) seviyelerini düşürüp yüksek yoğunluklu lipoprotein (HDL)'yi ve apolipoprotein A1 (Apo A1)'i artırdığını saptamıştır fakat Apo A1 ile ICAM-1 istatistiksel olarak sadece anlamlı bulunmuştur. Başka bir çalışmada, Gholamrezayi ve ark.,55 2019 yılında menopozlu 84 kadına 8 hafta günde 3 kez 300 mg kızılcık ekstratı takviyesinin, vücut ağırlığı, beden kütle indeksi (BKİ), bel çevresi, LDL/HDL oranı, TC/HDL oranı ile fibrinojende azalma sağladığını, HDL ile Apo A seviyeleri artırdığını saptamışlardır.

Literatürde kiraz grubu kırmızı meyve takviyesinin insülin yanıtında ve lipid metabolizması üzerinde etkisi olmadığını gösteren çalışmalara da rastlanmıştır. Kelley ve ark.,56 2006 yılındaki çalışmalarında sağlıklı 18 bireylerde 28 gün 280 g kiraz takviyesinin açlık kan şekeri, insülin ve kan yağlarını etkilemediğini göstermişlerdir. Lynn ve ark., ${ }^{2} 2014$ yılındaki çalışmalarında da sağlıklı 47 yetişkin bireye 6 hafta $30 \mathrm{ml}$ konsantre vişne suyu takviyesi sonucu CRP, TC ve HDL arasında bir fark gözlememişlerdir.

\section{Kardiyovasküler sistem üzerine etkisi}

Gut, eklemlerde ürik asidin kristalleşmesinden kaynaklanan dayanılmaz derecede ağrılı bir inflamatuar artrit hastalığıdır. Gut patofizyolojisi iyi karakterize edilmiş ve etkili farmakolojik tedaviler mevcutken, gut hastalarının çoğunda tekrarlayan gut atakları görülmeye devam etmektedir ve bu, morbidite riskinin en önemli nedenidir57. Yüksek antosiyanin içerikleri nedeniyle kiraz grubu kırmızı meyvelerin bu hastalarda olumlu sonuçlar verebileceği düşünülmektedir. 
Zhang ve ark.,57 2012 yılında yaptıkları bir çalışmada gut hastası olan 633 bireyde 2 gün boyunca günde 10-12 adet (1 porsiyon) taze kiraz takviyesinin, kiraz almayanlara kiyasla \%35 daha düşük gut atak riski ile ilişkilendirmiştir. Schumacher ve ark., ${ }^{8} 2013$ yılında yaptıkları bir çalışmada osteoartriti (OA) olan 46 yetişkin hastada 6 hafta $240 \mathrm{ml}$ vişne suyu takviyesi, hafif ve orta derecede diz OA'sı olan hastalar için semptomların hafifletilmesini sağlamış, ancak bu etki plasebo grubuna kıyasla istatistiksel olarak farklı bulunmamıştır. Vişne suyu CRP seviyelerini düşürmüş ve bu etki WOMAC (Western Ontario McMaster Osteoarthritis Index) skorlarındaki iyileşme ile ilişkilendirilmiştir.

KVH riskini arttıran bir diğer durum endotelyal disfonksiyondur ${ }^{9}$. Kelley ve ark., ${ }^{43} 2013$ yılında yaptıkları bir çalışmada sağlıklı 18 yetişkin bireye 28 gün, diyet karbonhidratları yerine 280 g kiraz takviyesinin, ET-1'in plazma konsantrasyonunu önemli ölçüde azalttığını bulmuşlardır. Bu sonuçlar KVH riskini azaltmak adına oldukça ümit vericidir.

\section{Hipertansiyon üzerine etkisi}

Hipertansiyon (HT) artan kan basıncı ile karakterize bir hastalık olup, NO üretiminde azalmanın ve ROS artışlarının bunu tetikledikleri gösterilmiştir. Ayrıca KVH gelişmesinde etken olan bir diğer kronik hastalıktır59.

Keane ve ark., ${ }^{60} 2016$ yılında yaptıkları çalışmalarında sağlıklı 27 yetişkin bireye $60 \mathrm{ml}$ konsantre vişne suyu takviyesinin 3 saat sonra sistolik kan basıncında (SBP) düşüşe yol açtığını göstermişlerdir. Aynı yıl yaptıkları diğer çalışmalarında da, HT hastası 15 erkeğe 14 gün $60 \mathrm{ml}$ konsantre vişne suyu takviyesinin alınmasından 1 ve 2 saat sonra sadece SBP'yi önemli ölçüde azalttığını bulmuşlardır ${ }^{61}$. Kent ve ark., ${ }^{62} 2017$ yılında yaptıkları bir çalışmada, demans hastası 49 yaşlıya 12 hafta $200 \mathrm{ml}$ kiraz suyu takviyesinin, SBP'de önemli bir azalmaya yol açtığını fakat diyastolik kan basıncındaki (DBP) azalmanın istatistiksel olarak anlamlı olmadığını gözlemlemişlerdir.

Literatürde kan basıncı üzerine hiçbir etki etkisi olmadığını gösteren çalışmalar olumlu etkilerini gösteren çalışmalardan fazladır. Örneğin, Ataie-Jafari ve ark., 542008 yılındaki çalışmalarında T2DM'li 19 kadına 6 hafta $400 \mathrm{ml} /$ gün vişne suyu takviyesinin SBP ve DBP’yi önemli ölçüde azaltmadığı gösterilmiştir. Kelley ve ark., 432013 yılında yaptıkları bir çalışmada sağlıklı 18 yetişkin bireye 28 gün, diyet karbonhidratları yerine 280 g kiraz takviyesinin, SBP'de istatistiksel olarak anlamlı olmayan bir azalmaya yol açtığını bulmuşlardır. Lynn ve ark., ${ }^{2} 2014$ yılındaki çalışmalarında da sağlıklı 47 yetişkin bireye 
6 hafta $30 \mathrm{ml}$ konsantre vişne suyu takviyesinin, SBP ve DBP'de bir farka yol açmadığını göstermişlerdir. Kent ve ark., ${ }^{63} 2016$ yılında yaptıkları çalışmada kontrolsüz HT’si ve disfajisi olan 6 genç ve 7 yaşlı bireye $300 \mathrm{ml}$ tek sefer ya da saatte bir 100 ml'lik 3 sefer şeklinde vişne suyu takviyesi sonucu, tek seferde $300 \mathrm{ml}$ vişne suyu, tüketiminden 2 saat sonra SBP ve DBP ile kalp atış hızında önemli bir azalmaya neden olmuş fakat 6 saat sonunda başlangıç seviyelerine dönmüştür. 2 saat boyunca sağlanan 3 dozluk $100 \mathrm{ml}$ vişne suyu da kan basıncında önemli bir düşüşe yol açmamıştır.

\section{Uyku, ruh hali ve bilişsel işlevler üzerindeki etkileri}

Kiraz grubu kırmızı meyvelerin içerdikleri melatonin nedeni ile uyku ile ilgili bozukluklar üzerinde etkili olabilecekleri düşünülmektedir ${ }^{64,65}$. Bu amaçla yapılan ilk pilot çalışmada 2010 yılında Pigeon ve ark., ${ }^{64}$ insomnia hastası 15 yaşlıya 2 hafta $240 \mathrm{ml}$ vişne suyu takviyesinin uykusuzluk şiddetinde (uyku başlangıcından sonra uyanık geçirilen dakikalar) önemli azalmalara yol açtığını; plaseboya kıyasla uyku gecikmesi, toplam uyku süresi veya uyku etkinliği için ise bir etkisi olmadığını göstermişlerdir. Howatson ve ark., ${ }^{65} 2012$ yılında yaptıkları bir çalışmada sağlıklı 20 yetişkin bireye 7 gün $30 \mathrm{ml}$ konsantre vişne suyunun sabah ve yatmadan $30 \mathrm{dk}$ önce takviyesinin toplam melatonin konsantrasyonunu; uyku süresi ve kalitesi ile zamanını arttırdığını bulmuşlardır. Garrido ve ark., ${ }^{66} 2013$ yılında yaptıkları çalışmalarında sağlıklı 10 genç, 10 orta yaşlı ve 10 yaşlı bireye 5 gün akşam ve öğle yemeklerinden sonra kiraz içeren bir kapsül takviyesinin, uyku etkinliği, uyanma sayısı, toplam gece aktivitesi, uyku gecikmesi, varsayılan uyku, gerçek uyku süresi ve hareketsizlik ile ölçülen gece dinlenmesini iyileştirdiği saptamışlardır.

Duygu durum bozuklukları nedeniyle depresyon ya da anksiyete yaygın olarak meydana gelmektedir. Serotonin ruh hali dahil olmak üzere bir çok fizyolojik ve davranışsal süreçlerin düzenlenmesinde önemli bir rol oynar ve triptofan, serotoninin doğrudan öncüsüdür67. Kirazların içerdikleri biyoaktif bileşenler arasında triptofandan da zengin oldukları ve duygu durum bozukluklarında etkili olabilecekleri düşünülmüşsür. Garrido ve ark., ${ }^{67} 2012$ yılında yaptıkları çalışmalarında sağlıklı 10 yetişkin bireye 5 gün kiraz içeren bir kapsül takviyesinin, idrarda kortizol seviyelerini azalttığını, 5hidroksidolaeasetik asit seviyelerini artırdığını gözlemlemişlerdir. Tersine, Keane ve ark., ${ }^{60} 2016$ yılında yaptıkları çalışmalarında sağlıklı 27 yetişkin bireye $60 \mathrm{ml}$ konsantre vişne suyu takviyesinin duygu durum ve bilişsel performansı 5 saat içinde 
değiştirmediğini göstermişlerdir. Yine, Caldwell ve ark. ${ }^{68} 2016$ yılındaki çalışmalarında, sağlıklı 6 genç ve 10 yaşlı bireye ( 5 sağlıklı, 5 demans) tek seferde $300 \mathrm{ml}$ vişne suyu takviyesi sonrasında 6 saat sonra test edilen bilişsel işlevlerde başlangıç düzeyine göre anlamlı bir fark olmadığını bulmuşlardır. Tablo 2'de kiraz grubu kırmızı meyvelerinin sağlık üzerine etkilerini değerlendiren çalışmaların özetleri sunulmuştur.

Tablo 2. Kiraz grubu kırmızı meyvelerin sağlık üzerine etkilerini değerlendiren klinik çalışmaların özetleri

\begin{tabular}{|c|c|c|c|}
\hline Çalışma grubu & $\begin{array}{l}\text { Kullanılan meyve, } \\
\text { süresi ve miktarı }\end{array}$ & Bulgular & Kaynak \\
\hline \multicolumn{4}{|c|}{ Antioksidan etkisi } \\
\hline $\begin{array}{l}\text { Sağlıklı kadın } \\
(\mathrm{n}=10)\end{array}$ & Kiraz, tek sefer $280 \mathrm{~g}$ & $\begin{array}{l}3 \text { saat sonra CRP ve NO seviyelerinde, } 5 \text { saat } \\
\text { sonra plazma ürat seviyelerinde azalma } \\
\text { görülmüştür. }\end{array}$ & $\begin{array}{l}\text { Jacob ve ark., } \\
2003^{39}\end{array}$ \\
\hline $\begin{array}{l}\text { Sağlıklı yaşlı } \\
(\mathrm{n}=12)\end{array}$ & $\begin{array}{l}\text { Vişne suyu, } 14 \text { gün } \\
240 \mathrm{ml}\end{array}$ & $\begin{array}{l}\text { Serum F2 isoprostan ve idrar 8-hidroksiguanosid } \\
\text { seviyelerinde azalma gösterilmiştir. }\end{array}$ & $\begin{array}{l}\text { Traustadottir ve } \\
\text { ark., 200940 }\end{array}$ \\
\hline $\begin{array}{l}\text { Sağlıklı yetişkin } \\
(\mathrm{n}=47)\end{array}$ & $\begin{array}{l}\text { Konsantre vişne suyu, } \\
6 \text { hafta } 30 \mathrm{ml}\end{array}$ & $\begin{array}{l}\text { Antioksidan biyobelirteçlerde TC ve HDL } \\
\text { seviyelerinde ile kan basıncı düzeylerinde bir } \\
\text { fark saptanmamıştır. }\end{array}$ & $\begin{array}{l}\text { Lynn ve ark., } \\
2014^{42^{*}}\end{array}$ \\
\hline $\begin{array}{l}\text { Direnç egzersizi } \\
\text { yapan erkek } \\
(\mathrm{n}=23)\end{array}$ & $\begin{array}{l}\text { Vişne içeren kapsül, } 10 \\
\text { gün } 480 \mathrm{mg}\end{array}$ & $\begin{array}{l}\text { Egzersiz sonrası kas ağrıları ve egzersizden } 48 \\
\text { saat sonra AST, ALT ve kreatinin seviyelerinde } \\
\text { azalma tespit edilmiştir. Serum antioksidan } \\
\text { biyobelirteçlerinde bir etkisine rastlanmamıştır. }\end{array}$ & $\begin{array}{l}\text { Levers ve ark., } \\
2015^{48^{* *}}\end{array}$ \\
\hline $\begin{array}{l}\text { Dayanıklılık } \\
\text { egzersizi yapan } \\
\text { yetişkin }(n=27)\end{array}$ & $\begin{array}{l}\text { Vişne içeren kapsül, } 10 \\
\text { gün } 480 \mathrm{mg}\end{array}$ & $\begin{array}{l}\text { Maraton süresinde iyileşme ve total antioksidan } \\
\text { seviyelerinde artış meydana gelmiştir. İdrar ürat } \\
\text { seviyelerinde artış, kreatinin, total protein ve } \\
\text { kortizol seviyelerinde azalma gözlenmiştir. }\end{array}$ & $\begin{array}{l}\text { Levers ve ark., } \\
2016^{49^{* *}}\end{array}$ \\
\hline $\begin{array}{l}\text { Su topu egzersizi } \\
\text { yapan erkek } \\
(\mathrm{n}=9)\end{array}$ & $\begin{array}{l}\text { Konsantre vişne suyu, } \\
6 \text { gün } 90 \mathrm{ml}\end{array}$ & $\begin{array}{l}\text { Serum antioksidan ve anti-inflamatuar } \\
\text { biyobelirteçlerinde bir fark saptanmamıştır. }\end{array}$ & $\begin{array}{l}\text { McCormick ve } \\
\text { ark., 201650** }\end{array}$ \\
\hline \multicolumn{4}{|c|}{ Anti-inflamatuar etki } \\
\hline $\begin{array}{l}\text { Maraton } \\
\text { koşucusu } \\
\text { yetişkin }(n=20)\end{array}$ & $\begin{array}{l}\text { Vişne suyu, } 7 \text { gün } 240 \\
\text { ml }\end{array}$ & $\begin{array}{l}\text { Egzersizle artan CRP, IL-6 ve kas hasarı ile } \\
\text { ağrısında azalma saptanmıştır. }\end{array}$ & $\begin{array}{l}\text { Howatson ve ark., } \\
2010^{46}\end{array}$ \\
\hline $\begin{array}{l}\text { Sağllklı yetişkin } \\
(\mathrm{n}=18)\end{array}$ & Kiraz, 28 gün $280 \mathrm{~g}$ & $\begin{array}{l}\text { Serum CRP seviyelerinde \%20, IL-18'de \%8,1, } \\
\text { AGE'lerde \%29, plazminojen aktivatör inhibitör- } \\
\text { 1'de \%19,9, ET-1'de \%13,7, ferritinde \%20,3 } \\
\text { oranında azalttığını ve IL-1'de \%27,9 oranında } \\
\text { artırdığını tespit etmişlerdir. ET-1 plazma } \\
\text { seviyelerinde önemli bir azalma saptanmıştır. } \\
\text { SBP'de azalma gözlense de istatistiksel olarak } \\
\text { anlamlı bulunmamıştır. }\end{array}$ & $\begin{array}{l}\text { Kelley ve ark., } \\
2013^{43^{* * *}}\end{array}$ \\
\hline $\begin{array}{l}\text { Sağllklı yetişkin } \\
(\mathrm{n}=12)\end{array}$ & $\begin{array}{l}\text { Konsantre vişne suyu, } \\
10 \text { gün } 30 \text { ya da } 60 \mathrm{ml}\end{array}$ & $\begin{array}{l}\text { CRP seviyesi azalmış fakat ürik asit seviyelerinde } \\
\text { önemli bir fark gözlenmemiştir. }\end{array}$ & Bell ve ark., 201445 \\
\hline
\end{tabular}




\begin{tabular}{|c|c|c|c|}
\hline $\begin{array}{l}\text { Bisiklet sürme } \\
\text { egzersizi yapan } \\
\text { yetişkin }(n=16)\end{array}$ & $\begin{array}{l}\text { Konsantre vişne suyu, } \\
3 \text { gün } 30 \mathrm{ml}\end{array}$ & $\begin{array}{l}\text { CRP, IL-6 ve lipid hidroperoksitlerinde azalma } \\
\text { meydana gelmiştir. }\end{array}$ & Bell ve ark., $2014^{47}$ \\
\hline $\begin{array}{l}\text { Hafif kilolu ve } \\
\text { obez yetişkin } \\
(\mathrm{n}=26)\end{array}$ & $\begin{array}{l}\text { Vişne suyu, } 4 \text { hafta } \\
240 \mathrm{ml}\end{array}$ & $\begin{array}{l}\text { Serum ürat \%19,2, CRP \%19,4 ve monosit } \\
\text { kemoatraktan protein-1 seviyeleri \%6,3 oranında } \\
\text { azalma göstermiştir. }\end{array}$ & $\begin{array}{l}\text { Martin ve ark., } \\
2019^{44}\end{array}$ \\
\hline \multicolumn{4}{|c|}{ Diyabet ve kan lipidleri üzerine etkisi } \\
\hline $\begin{array}{l}\text { Sağllklı yetişkin } \\
(\mathrm{n}=18)\end{array}$ & Kiraz, 28 gün $280 \mathrm{~g}$ & $\begin{array}{l}\text { Açlık kan şekeri, insülin ve kan yağları üzerine } \\
\text { bir etkisi saptanmamıştır. }\end{array}$ & $\begin{array}{l}\text { Kelley ve ark., } \\
2006^{56}\end{array}$ \\
\hline $\begin{array}{l}\text { T2DM'li kadın } \\
(\mathrm{n}=19)\end{array}$ & $\begin{array}{l}\text { Vişne suyu, } 6 \text { hafta } \\
400 \mathrm{ml}\end{array}$ & $\begin{array}{l}\text { Açlık kan şekerini \%8 oranında azalmaya yol } \\
\text { açmış; vücut ağırlığı, kan basıncı, HbA1c, TC ve } \\
\text { LDL seviyelerinde de azalma gösterilmiştir. }\end{array}$ & $\begin{array}{l}\text { Ataie-Jafari ve } \\
\text { ark., 200853 }\end{array}$ \\
\hline $\begin{array}{l}\text { T2DM'li yetişkin } \\
(\mathrm{n}=60)\end{array}$ & $\begin{array}{l}\text { Kızılcıktan izole edilen } \\
\text { antosiyanin, } 6 \text { hafta } \\
300 \text { mg (günde } 2 \text { kez) }\end{array}$ & $\begin{array}{l}\text { İnsülin seviyelerinde artış, HbA1c ve TG } \\
\text { seviyelerinde azalma meydana gelmiştir. }\end{array}$ & $\begin{array}{l}\text { Soltani ve ark., } \\
2015^{54}\end{array}$ \\
\hline $\begin{array}{l}\text { Dislipidemik } \\
\text { çocuk ve } \\
\text { adölesan }(n=40)\end{array}$ & $\begin{array}{l}\text { Kızlcık, } 6 \text { hafta } 50 \mathrm{~g} \\
\text { (günde } 2 \text { kez) }\end{array}$ & $\begin{array}{l}\text { TC, TG, LDL, Apo B, ICAM-1, VCAM-1 } \\
\text { seviyelerinde azalma; HDL ve Apo A1 } \\
\text { seviyelerinde artış gözlenmiştir. }\end{array}$ & $\begin{array}{l}\text { Asgary ve ark., } \\
2013^{16}\end{array}$ \\
\hline $\begin{array}{l}\text { Menopozlu } \\
\text { kadın }(n=84)\end{array}$ & $\begin{array}{l}\text { Kizılcık ekstratı, } 8 \\
\text { hafta } 300 \text { mg }\end{array}$ & $\begin{array}{l}\text { Vücut ağırlığı, BKİ, bel çevresi, LDL/HDL oranı, } \\
\text { TC/HDL oranı ile fibrinojen seviyelerinde } \\
\text { azalma; HDL ve Apo A seviyelerinde artış } \\
\text { meydana gelmiştir. }\end{array}$ & $\begin{array}{l}\text { Gholamrezayi ve } \\
\text { ark., } 2019^{55}\end{array}$ \\
\hline \multicolumn{4}{|c|}{ Kardiyovasküler sistem üzerine etkisi } \\
\hline $\begin{array}{l}\text { Gut hastası } \\
\text { yetişkin }(n=633)\end{array}$ & Kiraz, 2 gün $10-12$ adet & Gut ataklarında \%35 azalma bulunmuştur. & $\begin{array}{l}\text { Zhang ve ark., } \\
2012^{57}\end{array}$ \\
\hline $\begin{array}{l}\text { OA hastası } \\
\text { yetişkin }(n=46)\end{array}$ & $\begin{array}{l}\text { Vişne suyu, } 6 \text { hafta } \\
240 \mathrm{ml}\end{array}$ & $\begin{array}{l}\text { Hafif ve orta diz OA'sı olan hastalarda } \\
\text { semptomlarda hafiflemeye CRP seviyelerinde } \\
\text { azalma gösterilmiştir. }\end{array}$ & $\begin{array}{l}\text { Schumacher ve } \\
\text { ark., } 2013^{58}\end{array}$ \\
\hline \multicolumn{4}{|c|}{ Hipertansiyon üzerine etkisi } \\
\hline $\begin{array}{l}\text { Sağllkl yetişkin } \\
(\mathrm{n}=27)\end{array}$ & $\begin{array}{l}\text { Konsantre vişne suyu, } \\
\text { tek sefer } 60 \mathrm{ml}\end{array}$ & $\begin{array}{l}3 \text { saat sonra SBP'de düşüş gözlenmiş; duygu } \\
\text { durum ve bilişsel performans üzerine bir etkisi } \\
\text { gösterilmemiştir. }\end{array}$ & $\begin{array}{l}\text { Keane ve ark., } \\
2016^{60^{* * * * *}}\end{array}$ \\
\hline $\begin{array}{l}\text { HT hastası erkek } \\
(\mathrm{n}=15)\end{array}$ & $\begin{array}{l}\text { Konsantre vişne suyu, } \\
14 \text { gün } 60 \mathrm{ml}\end{array}$ & $\begin{array}{l}1 \text { ve } 2 \text { saat sonra sadece SBP'nin önemli ölçüde } \\
\text { azaldığı bulunmuştur. }\end{array}$ & $\begin{array}{l}\text { Keane ve ark., } \\
2016^{61}\end{array}$ \\
\hline $\begin{array}{l}\text { Kontrolsüz HT'si } \\
\text { ve disfajisi olan } \\
\text { genç }(n=6) \text { ve } \\
\text { yaşlı }(n=7)\end{array}$ & $\begin{array}{l}\text { Kiraz suyu, tek sefer } \\
300 \mathrm{ml} \text { ya da } 3 \mathrm{kez} \\
\text { 100'er ml }\end{array}$ & $\begin{array}{l}\text { Tek doz tüketim } 2 \text { saat sonunda SBP ve DBP'de } \\
\text { azalma gösterse de } 6 \text { saat sonra başlangıç } \\
\text { seviyelerine dönmüşlerdir. } 3 \text { doz şeklinde } \\
\text { tüketim kan basıncını etkilememiştir. }\end{array}$ & $\begin{array}{l}\text { Kent ve ark., } \\
2016^{63}\end{array}$ \\
\hline $\begin{array}{l}\text { Demans hastası } \\
\text { yaşlı }(n=49)\end{array}$ & $\begin{array}{l}\text { Kiraz suyu, } 12 \text { hafta } \\
200 \mathrm{ml}\end{array}$ & $\begin{array}{l}\text { SBP'de önemli bir azalma meydana gelmişken } \\
\text { DBP'teki azalma istatistiksel olarak anlamlı } \\
\text { bulunmamışır. }\end{array}$ & $\begin{array}{l}\text { Kent ve ark., } \\
2017^{62}\end{array}$ \\
\hline \multicolumn{4}{|c|}{ Uyku, ruh hali ve bilişsel performans üzerine etkileri } \\
\hline $\begin{array}{l}\text { İnsomnia } \\
\text { hastası yaşlı } \\
(\mathrm{n}=15)\end{array}$ & $\begin{array}{l}\text { Vişne suyu, } 2 \text { hafta } \\
240 \mathrm{ml}\end{array}$ & $\begin{array}{l}\text { Uykusuzluk şiddetinde önemli bir azalma } \\
\text { gözlenmiştir. }\end{array}$ & $\begin{array}{l}\text { Pigeon ve ark., } \\
2010^{64}\end{array}$ \\
\hline
\end{tabular}




\begin{tabular}{|c|c|c|c|}
\hline $\begin{array}{l}\text { Sağlıklı yetişkin } \\
(\mathrm{n}=20)\end{array}$ & $\begin{array}{l}\text { Konsantre vişne suyu, } \\
7 \text { gün } 30 \text { ml (günde } 2 \\
\text { kez) }\end{array}$ & $\begin{array}{l}\text { Uyku süresinde ve kalitesinde artış meydana } \\
\text { gelmiştir. }\end{array}$ & $\begin{array}{l}\text { Howatson ve ark., } \\
2012^{65}\end{array}$ \\
\hline $\begin{array}{l}\text { Sağlıklı yetişkin } \\
(\mathrm{n}=10)\end{array}$ & $\begin{array}{l}\text { Kiraz içeren kapsül, } 5 \\
\text { gün } 30 \text { mg antosiyanin }\end{array}$ & $\begin{array}{l}\text { İdrarda kortizol seviyelerinde azalma ve } 5^{-} \\
\text {hidroksidolaeasetik asit seviyelerinde artış } \\
\text { gösterilmiştir. }\end{array}$ & $\begin{array}{l}\text { Garrido ve ark., } \\
2012^{67}\end{array}$ \\
\hline $\begin{array}{l}\text { Sağlıklı genç ve } \\
\text { yaşlı }(\mathrm{n}=20)\end{array}$ & $\begin{array}{l}\text { Kiraz içeren kapsül, } 5 \\
\text { gün } 30 \text { mg antosiyanin } \\
\text { (günde } 2 \mathrm{kez} \text { ) }\end{array}$ & $\begin{array}{l}\text { Uyku etkinliği, uyanma sayısı, toplam gece } \\
\text { aktivitesi, uyku gecikmesi, varsayılan uyku, } \\
\text { gerçek uyku süresi ve hareketsizlik ile ölçülen } \\
\text { gece dinlenmesinde iyileşme bulunmuştur. }\end{array}$ & $\begin{array}{l}\text { Garrido ve ark., } \\
2013^{66}\end{array}$ \\
\hline $\begin{array}{l}\text { Sağllklı genç } \\
(n=6) \text { ve yaşlı } \\
(n=5) \text {, demans } \\
\text { hastası yaşlı } \\
(n=5)\end{array}$ & $\begin{array}{l}\text { Vişne suyu, tek sefer } \\
300 \mathrm{ml}\end{array}$ & Bilişsel performans üzerine etki göstermemiştir. & $\begin{array}{l}\text { Caldwell ve ark., } \\
2016^{68}\end{array}$ \\
\hline
\end{tabular}

\footnotetext{
* Aantioksidan, kan lipidleri ve kan basıncı üzerine etkisi, ${ }^{* *}$ Antioksidan ve antiinflamatuar etki, ${ }^{* * *}$ Anti-inflamatuar, kan basıncı ve KVH üzerine etkisi, ${ }^{* * *}$ HT ve duygu durum üzerine etkisi, CRP: C-reaktif protein, NO: nitrit oksit, TC: total kolesterol, HDL: yüksek yoğunluklu lipoprotein, AST: aspartam aminotransferaz, ALT: alanin aminotransferaz, IL-6: interlökin-6, IL-18; interlökin-18, IL-1: interlökin-1, ET-1: endotelin-1, SBP: sistolik kan basinc1, HbA1c: hemoglobin A1c, LDL: düşük yoğunluklu lipoprotein, TG: trigliserit, Apo B: apolipoprotein B, ICAM-1: hücre içi adhezyon molekülü-1, VCAM-1: vasküler hücre adezyon molekülü 1, Apo A1: apolipoprotein A1, OA: osteoartrit, DBP: diyastolik kan basıncı
}

\section{Tartışma}

Son yıllarda, beslenmenin birçok hastalık ve ilişkili komplikasyonları önlemede önemli bir rolü olduğuna inanılmaktadır. Bu nedenle sağlıklı yaşam tarzları popüler olmakta ve sağlıklı diyetlere ve şifalı bitkilere olan ilgi giderek artmaktadır. Artan epidemiyolojik kanttlar bitkilerin hastalıklara bağlı semptomları azalttığı inancını desteklemektedir ${ }^{10-13}$. Antosiyaninler en güçlü doğal antioksidanlardan biri olup, kırmızı meyveler, tüm meyveler arasında en zengin antosiyanin kaynaklarıdır. Bu derleme, antosiyanince zengin kiraz grubu kırmızı meyvelerin sağlığı olumlu yönde etkileyerek antioksidan $39,40,42,48-50$, anti-inflamatuar ${ }^{43,44,46-49}$, anti diyabetik54,55, hipolipidemik ${ }^{16,53-55}$, artrit ve endotelyal disfonksiyon ${ }^{43,57,58}$ ile hipertansiyon ${ }^{60-62}$ üzerine pozitif etki göstererek kardiyovasküler sistemi koruyucu ve uyku ${ }^{64-66}$ ile ruh hali67 üzerinde olumlu etkileri olabileceğini göstermiş̧ir.

Türkiye, obezite prevalansı gün geçtikçe artmakta olan bir ülke olup, DSÖ’nün son raporuna göre Avrupa ülkeleri arasında \%32,1'lik oranla birinci sıradadır ${ }^{69}$. Bu durum 
KVH riski, bozulmuş glikoz toleransı ve dislipidemi ile ilişkilidir. Ayrıca, özellikle abdominal obezite, ilerlemiş vasküler komplikasyonlara yol açan çeşitli metabolik bozukluklar ve endotelyal disfonksiyon ile de ilişkilendirilmektedir ${ }^{70}$. Bu nedenle bu durumun kontrol altına alınması, alternatif tedavi yollarının bulunması önem arz etmektedir.

İnsülin direnci ve DM prevalansı, artan batı tarzı beslenmeyle birlikte gün geçtikçe Türkiye'de ve dünyada artmaktadır. Kiraz grubu kırmızı meyvelerin DM üzerindeki olumlu etkileri yapılan klinik çalışmalarla gösterilmiştir54,55. Bu etkilerini pankreas $\beta$ hücre fonksiyonlarını ve periferik doku insülin duyarlılı̆̆ını artırma, gastrointestinal sistemde karbonhidrat parçalanması ve glikoz emiliminde yer alan sindirim enzimlerinin inhibisyonu ve enerji metabolizmasını düzenleme ile gerçekleştirmektedir ${ }^{71}$. Bunların tersine açlık kan glikozu ve insülin düzeyleri üzerinde herhangi bir etkisinin olmadığı da gösterilmiştir56. Birlikte ele alındığında, kiraz grubu kırmızı meyve tüketiminin sağlıklı glikoz regülasyonunu teşvik edebileceğini gösteren kanıtlar olsa da bu bulguların azalmış diyabet riskine dönüşüp dönüşmediğini doğrulamak için daha fazla klinik çalışmaya ihtiyaç vardır.

Kiraz grubu kırmızı meyvelerin lipid metabolizması üzerine olan etkisini değerlendiren çalışmaların sonuçlarına göre TC, TG, LDL’yi düşürücü etkisi gösterilse de ${ }^{16,53-55}$, hiçbir etkisi olmadığını gösteren çalışmaya da rastlanmıştır42 ${ }^{2}$ Çalışmalara bakıldığında olumlu etkiler vişne ve kızılcıkta gösterilmiştir. $\mathrm{Bu}$ meyvelerin lipid profili üzerine etkinliği değerlendirebilmek için farklı kiraz grubu meyve türlerinin takviyesinin insanlar üzerindeki etkinliğinin incelenmesi gerekmektedir.

Romatoid artrit kronik bir inflamatuar hastalık olmakla beraber KVH’lardan ölüm en çok bu hastalık sebebiyle meydana gelmektedir ${ }^{44}$. Kiraz grubu kırmızı meyvelerinin artritli hastalarda ürik asit seviyelerini azaltarak, artrit ataklarının azalmasına yol açtıkları gösterilmiştir ${ }^{8}$. Ayrıca gut ataklarında azalma sağladıkları da rapor edilmiştir57. Yine KVH riskini artıran endotelyal disfonksiyon üzerinde de kirazın olumlu etkisi gösterilse de yapılan klinik çalışmalar bunlarla sınırlıdır43.

Artan kan basıncı, endotelyal disfonksiyon, ROS artışı ile NO üretiminde azalma sonucu oluşan HT ile KVH arasında da güçlü bir bağlantı bulunmaktadır59. Literatürde kiraz grubu kırmızı meyvelerin HT üzerine olan etkilerini değerlendiren çalışmaların sonuçları 
çelişkilidir. Olumlu etkilerini gösteren çalışmalar hem sağlıklı hem HT hastası olan bireylere verilen kiraz ve vişne takviyeleri ile gözlenmiştir ${ }^{60-62}$. Kan basıncı üzerine etkisi olmayan çalışma gruplarının dağılımları farklılık göstermekle birlikte sağlıklı ya da başka kronik hastalığı olan popülasyonlarda tasarlanmış olup, bu nedenle herhangi bir etki gözlenmemiş olabilir. Ayrıca yapılan çalışmaların takviye dozları ya da sürelerinin kısalığı da diğer etkenlerdir.

Melatonin salgılanması gece/gündüz döngülerden etkilenir ve sonuçta uyku/uyanıklık döngüsünü etkiler. Fizyolojik açıdan bakıldığında, endojen melatoninin gece vücut ısısını etkilediği ve uykuyu kolaylaştırdığı göz önüne alındığında, artan ekzojen melatoninin vücut ısısındaki değişiklikleri daha da kolaylaştıracağı ve dolayısıyla uyku kalitesindeki iyileşmelerden sorumlu olacağı düşünülmektedir65. Kiraz grubu kırmızı meyvelerin melatonin içerdiği ve bu nedenle uyku süresi, derinliği ve kalitesini iyileşmelere yol açabildiği gösterilse de çalışmalar oldukça sınırlıdır64-66.

Stresten kaynaklanan yüksek kortizol düzeyleri serotonin seviyelerini azaltmakta ve depresyona yol açabilmektedir. Bazı yerlerde yetiştirilen kiraz çeşitlerinde serotonin öncüsü olan triptofan amino asidi bulunduğu ve bunun kortizol seviyesini azaltarak duygu durum bozukluğunu düzelttiği gösterilse de $^{67}$ bilişsel performans üzerine etkisine rastlanamamıştır60,68. Çalışmalar tek doz şeklinde verildiği için herhangi bir etki saptanamamış olabilir. Çelişkili sonuçlar nedeniyle insanlar üzerinde kesin bir değerlendirme yapılamamaktadır.

\section{Sonuç}

Özellikle antosiyanince zengin olan ve başka birçok biyoaktif bileşen bulundurmaları nedeniyle antioksidan kapasiteleri oldukça yüksek olan kiraz grubu kırmızı meyvelerin sağlığı olumlu yönde etkilediği ve bazı kronik hastalıkların ilerlemesini önlediği gösterilse de yapılan klinik çalışmalar sınırlı sayıdadır. Benzer şekilde sağlığı olumlu yönde etkileyebileceği gösterilen antosiyanince zengin bir diğer grup olan üzümsü kırmızı meyvelerinde klinik çalışmalarla etkinliği literatürde gösterilse de bu konu ile ilgili yapılan derleme çalışmaları sınırlıdır. Güncel klinik çalışmalar kiraz grubu kırmızı meyvelerin sağlı̆̆ı olumlu yönde etkilediği konusunda oldukça umut verici olsa da kesin mekanizmalarının ve sonuçlarının aydınlatılabilmesi adına insanlar üzerinde yapılacak daha fazla kapsamlı çalışmaya ihtiyaç vardır. Ayrıca incelenen çalışmalar arasında 
Türkiye'de insanlar üzerinde yapılmış bir klinik çalışmaya rastlanmamış olup, ülkemizin meyve üretiminde dünyada dördüncü sırada yer alarak, önde gelen ülkelerden biri olması nedeniyle bu konuya olan bilimsel ilginin arttırılması önemlidir.

\section{KAYNAKLAR}

1. Önem E. Vişne ve insan sağlığı. Meyve Bilimi. 2017;4(2):1-5.

2. Robinson MM, Zhang X. The World medicines situation 2011 traditional medicines: global situation, issues and challenges. Geneva: WHO; 2011.

3. Palhares RM, Drummond MG, Brasil BSAF, Cosenza GP, Brandao MGL, Oliveira G. Medicinal plants recommended by the world health organization: DNA barcode identification associated with chemical analyses guarantees their quality. PLoS One. 2015;10(5):e0127866. doi:10.1371/journal.pone.0127866.

4. World Health Organization. WHO global report on traditional and complementary medicine. Geneva; 2019.

5. Bulut G, Haznedaroğlu MZ, Doğan A, Koyu H, Tuzlacı E. An ethnobotanical study of medicinal plants in Acipayam (Denizli-Turkey). J Herb Med. 2017;10:64-81. doi: 10.1016/j.hermed.2017.08.001.

6. Paksoy MY, Selvi S, Savran A. Ethnopharmacological survey of medicinal plants in Ulukışla (Niğde-Turkey). J Herb Med. 2016;6(1):42-48. doi:10.1016/j.hermed.2015.04.003.

7. Sargin SA, Büyükcengiz M. Plants used in ethnomedicinal practices in Gulnar district of Mersin, Turkey. $J$ Herb Med. 2019;15(3):100224. doi:10.1016/j.hermed.2018.06.003.

8. Polat R. Ethnobotanical study on medicinal plants in Bingöl (City center) (Turkey). J. Herb. Med. 2019;16:100211. doi: 10.1016/j.hermed.2018.01.007.

9. Stull AJ, Cash KC, Champagne CM, et al. Blueberries improve endothelial function, but not blood pressure, in adults with metabolic syndrome: A randomized, double-blind, placebo-controlled clinical trial. Nutrients. 2015;7(6):4107-4123. doi:10.3390/nu7064107. 
10. Kelley DS, Adkins Y, Laugero KD. A review of the health benefits of cherries. Nutrients. 2018;10(3):368. doi: 10.3390/nu10030368.

11. Zhan J, Liu YJ, Cai LB, Xu FR, Xie T, He QQ. Fruit and vegetable consumption and risk of cardiovascular disease: A meta-analysis of prospective cohort studies. Crit Rev Food Sci Nutr. 2017;57(8):1650-1663. doi:10.1080/10408398.2015.1008980.

12. Cooper AJ, Forouhi NG, Ye Z, et al. Europe PMC funders group fruit and vegetable intake and type 2 diabetes : EPIC-InterAct prospective study and meta-analysis. Eur J Clin Nutr. 2012;66(10):1082-1092. doi: 10.1038/ejcn.2012.85.

13. Liu J, Wang J, Leng Y, Lv C. Intake of fruit and vegetables and risk of esophageal squamous cell carcinoma: A meta-analysis of observational studies. Int. J. Cancer. 2013;133(2):473-485. doi: 10.1002/ijc.28024.

14. Szczepaniak OM, Kobus-Cisowska J, Kusek W, Przeor M. Functional properties of cornelian cherry (Cornus mas L.): a comprehensive review. Eur Food Res Technol. 2019;245(10):2071-2087. doi: 10.1007/soo217-019-03313-0.

15. Bisson J, McAlpine JB, Friesen JB, Chen SN, Graham J, Pauli GF. Can invalid bioactives undermine natural product-based drug discovery? J Med Chem. 2016;59(5):1671-1690. doi: 10.1021/acs.jmedchem.5bo10o9.

16. Asgary S, Kelishadi R, Rafieian-Kopaei M, Najafi S, Najafi M, Sahebkar A. Investigation of the lipid-modifying and antiinflammatory effects of Cornus mas L. supplementation on dyslipidemic children and adolescents. Pediatr. Cardiol. 2013;34(7):1729-1735. doi: 10.1007/s00246-013-0693-5.

17. Olas B. Berry phenolic antioxidants-implications for human health? Front Pharmacol. 2018;9:78. doi: 10.3389/fphar.2018.00078.

18. Hidalgo GI, Almajano MP. Red fruits: Extraction of antioxidants, phenolic content, and radical scavenging determination: A review. Antioxidants. 2017;6:7. doi: 10.3390/antiox6010007. 
19. Tarım ve Orman Bakanlığı. Bitkisel Üretim Verileri 2019.

http://tuikweb.tuik.gov.tr/. Yayınlanma tarihi 2019. Erişim tarihi 24 Mayıs 2020.

20. Göksel Z, Aksoy U. Sofralık bazı kiraz çeşitlerinin fizikokimyasal özellikleri. Türk Tartm ve Doğa Bilim Derg. 2014;2:1856-1862.

21. Dinda B, Kyriakopoulos AM, Dinda S, et al. Cornus mas L. (cornelian cherry), an important European and Asian traditional food and medicine: Ethnomedicine, phytochemistry and pharmacology for its commercial utilization in drug industry. $J$ Ethnopharmacol. 2016;193(4):670-690. doi: 10.1016/j.jep.2016.09.042.

22. Çağlar MY, Demirci M. Üzümsü meyvelerde bulunan fenolik bileşikler ve beslenmedeki önemi. EJOSAT. 2017;7(11):18-26.

23. Blando F, Oomah BD. Sweet and sour cherries: Origin, distribution, nutritional composition and health benefits. Trends Food Sci Technol. 2019;86(2):517-529. doi: 10.1016/j.tifs.2019.02.052.

24. Karlidag H, Ercisli E, Sengul M, Tosun M. Physico-chemical diversity in fruits of wild-growing sweet cherries (Prunus Avium L.). Biotechnol. Biotechnol. Equip. 2009;23(3):1325-1329. doi: 10.1080/13102818.2009.10817663.

25. Capanoglu E, Boyacioglu D, de Vos RCH, Hall RD, Beekwilder J. Procyanidins in fruit from sour cherry (Prunus cerasus) differ strongly in chainlength from those in laurel cherry (Prunus lauracerasus) and cornelian cherry (Cornus mas). J Berry Res. 2011;1(3):137-146. doi: 10.3233/BR-2011-015.

26. Hayaloglu AA, Demir N. Physicochemical characteristics, antioxidant activity, organic acid and sugar contents of 12 sweet cherry (prunus avium 1.) cultivars grown in Turkey. $J$ Food Sci. 2015;80(3):564-570. doi: 10.1111/17503841.12781 .

27. Celep E, Aydin A, Yesilada E. A comparative study on the in vitro antioxidant potentials of three edible fruits: Cornelian cherry, Japanese persimmon and cherry laurel. Food Chem Toxicol. 2012;50(9):3329-3335. doi: 10.1016/j.fct.2012.06.010. 
28. Onur OT, Serencam H, Baltas N, Can Z. Some edible forest fruits their in vitro antioxidant activities, phenolic compounds and some enzyme inhibition effects. Fresenius Environmental Bulletin. 2019;28(8): 6090-6098.

29. Yılmaz FM, Karaaslan M, Vardin H. Optimization of extraction parameters on the isolation of phenolic compounds from sour cherry (Prunus cerasus L.) pomace. J Food Sci Technol. 2015;52(5):2851-2859. doi: 10.1007/s13197-0141345-3.

30. Hayaloglu AA, Demir N. Phenolic Compounds, volatiles, and sensory characteristics of twelve sweet cherry (Prunus avium L.) cultivars grown in Turkey. J Food Sci. 2016;81(1):7-18. doi: 10.1111/1750-3841.13175.

31. Kelebek H, Selli S. Evaluation of chemical constituents and antioxidant activity of sweet cherry (Prunus avium L.) cultivars. Int $J$ Food Sci Technol. 2011;46(12):2530-2537. doi: 10.1111/j.1365-2621.2011.02777.x.

32. DeBiaggi M, Donno D, Mellano MG, Riondato I, Rakotoniaina EN, Beccaro GL. Cornus mas (L.) Fruit as a potential source of natural health-promoting compounds: physico-chemical characterisation of bioactive components. Plant Foods Hum Nutr. 2018;73(2):89-94. doi: 10.1007/s11130-018-0663-4.

33. Drkenda P, Spahic A, Begic-Akagic A, et al. Pomological characteristics of some autochthonous genotypes of cornelian cherry (Cornus mas L.) in Bosnia and Herzegovina. Erwerbs-Obstbau. 2014;56(2):59-66. doi: 10.1007/s10341-0140203-9.

34. Begic-Akagic A, Drkenda P, Vranac A, Orazem P, Hudina M. Influence of growing region and storage time on phenolic profile of cornelian cherry jam and fruit. Eur J Hortic Sci. 2013;78(1):30-39.

35. Pawlowska AM, Camangi F, Braca A. Quali-quantitative analysis of flavonoids of Cornus mas L. (Cornaceae) fruits. Food Chem. 2010;119(3):1257-1261. doi: 10.1016/j.foodchem.2009.07.063. 
36. Dzydzan O, Bila I, Kucharska AZ, Brodyak I, Sybirna N. Antidiabetic effects of extracts of red and yellow fruits of cornelian cherries (Cornus mas L.) on rats with streptozotocin-induced diabetes mellitus. Food Funct. 2019;10(10):64596472. doi: 10.1039/c9fooo515c.

37. Kalyoncu IH, Ersoy N, Yilmaz M. Physico-chemical and nutritional properties of cornelian cherry fruits (Cornus mas L.) grown in Turkey. Asian $J$ Chem. 2009;21(8):6555-6561.

38. Yuan Q, Zhao L. The Mulberry (Morus alba L.) Fruit - A review of characteristic components and health benefits. J Agric Food Chem. 2017;65(48):1038310394. doi: 10.1021/acs.jafc.7bo3614.

39. Jacob RA, Spinozzi GM, Simon VA, Kelley DS, Prior RL, Hess-Pierce B, et al.. Consumption of cherries lowers plasma urate in healthy women. ASN. 2003;113(6):1826-1829. doi: 10.1093/jn/133.6.1826.

40. Traustadottir T, Davies SS, Stock AA, et al. Tart cherry juice decreases oxidative stress in healthy older men and women. J Nutr. 2009;139(10):18961900. doi: 10.3945/jn.109.111716.

41. Kresty LA, Frankel WL, Hammond CD, et al. Transitioning from preclinical to clinical chemopreventive assessments of lyophilized black raspberries: Interim results show berries modulate markers of oxidative stress in Barrett's Esophagus patients. Nutr Cancer. 2006;54(1):148-156. doi: 10.1207/s15327914nc5401_15.

42. Lynn A, Mathew S, Moore CT, et al. Effect of a tart cherry juice supplement on arterial stiffness and inflammation in healthy adults: A randomised controlled trial. Plant Foods Hum Nutr. 2014;69(2):122-127. doi: 10.1007/s11130-0140409-x.

43. Kelley DS, Adkins Y, Reddy A, Woodhouse LR, Mackey BE, Erickson KL. Sweet bing cherries lower circulating concentrations of markers for chronic inflammatory diseases in healthy humans. $J$ Nutr. 2013;143(3):340-344. doi: 10.3945/jn.112.171371. 
44. Martin KR, Coles KM. Consumption of 100\% tart cherry juice reduces serum urate in overweight and obese adults. Curr Dev Nutr. 2019;3:nzzo11. doi: 10.1093/cdn/nzzO11.

45. Bell PG, Gaze DC, Davison GW, George TW, Scotter MJ, Howatson G. Montmorency tart cherry (Prunus cerasus L.) concentrate lowers uric acid, independent of plasma cyanidin-3-O-glucosiderutinoside. J. Funct. Foods. 2014;11:82-90. doi: 10.1016/j.jff.2014.09.004.

46. Howatson G, McHugh MP, Hill A, et al. Influence of tart cherry juice on indices of recovery following marathon running. Scand $J$ Med Sci Sport. 2010;20(6):843-852. doi: 10.1111/j.1600-0838.2009.01005.x.

47. Bell PG, Walshe IH, Davison GW, Stevenson E, Howatson G. Montmorency cherries reduce the oxidative stress and inflammatory responses to repeated days high-intensity stochastic cycling. Nutrients. 2014;6:829-843. doi: 10.3390/nu6o20829.

48. Levers K, Dalton R, Galvan E, et al. Effects of powdered Montmorency tart cherry supplementation on an acute bout of intense lower body strength exercise in resistance trained males. J Int Soc Sports Nutr. 2015;12(1):42. doi: 10.1186/s12970-015-0102-y.

49. Levers K, Dalton R, Galvan E, et al. Effects of powdered Montmorency tart cherry supplementation on acute endurance exercise performance in aerobically trained individuals. J Int Soc Sports Nutr. 2016;13:22. doi: 10.1186/s12970-016o133-z.

50. McCormick R, Peeling P, Binnie M, Dawson B, Sim M. Effect of tart cherry juice on recovery and next day performance in well-trained Water Polo players. J Int Soc Sports Nutr. 2016;13:41. doi: 10.1186/s12970-016-0151-x.

51. Seeram NP. Emerging research supporting the positive effects of berries on human health and disease prevention. J Agric Food Chem. 2012;60(23):56855686. doi: 10.1021/jf203455Z. 
52. Basu A. Role of berry bioactive compounds on lipids and lipoproteins in diabetes and metabolic syndrome. Nutrients. 2019;11(9):1983. doi: 10.3390/nu11091983.

53. Ataie-Jafari A, Hosseini S, Karimi F, Pajouhi M. Effects of sour cherry juice on blood glucose and some cardiovascular risk factors improvements in diabetic women A pilot study. Nutr Food Sci. 2008;38(4):355-360. doi: 10.1108/00346650810891414.

54. Soltani R, Gorji A, Asgary S, Sarrafzadegan N, Siavash M. Evaluation of the Effects of Cornus mas L. fruit extract on glycemic control and insulin level in type 2 diabetic adult patients: A randomized double-blind placebo-controlled clinical trial. Evidence-based Complement Altern Med. 2015;2015:740954. doi: $10.1155 / 2015 / 740954$.

55. Gholamrezayi A, Aryaeian N, Rimaz S, et al. The effect of Cornus mas fruit extract consumption on lipid profile, glycemic indices, and leptin in postmenopausal women- A randomized clinical trial. Phyther Res. 2019;33(11):2979-2988. doi: 10.1002/ptr.6476.

56. Kelley DS, Rasooly R, Jacob RA, Kader AA, Mackey BE. Consumption of bing sweet cherries lowers circulating concentrations of inflammation markers in healthy men and women. $J$ Nutr. 2006;136(4):981-986. doi: 10.1093/jn/136.4.981.

57. Zhang Y, Neogi T, Chen C, Chaisson C, Hunter DJ, Choi HK. Cherry consumption and decreased risk of recurrent gout attacks. Arthritis Rheum. 2012;64(12):4004-4011. doi: 10.1002/art.34677.

58. Schumacher HR, Pullman-Mooar S, Gupta SR, Dinnella JE, Kim J, McHugh MP. Randomized double-blind crossover study of the efficacy of a tart cherry juice blend in treatment of osteoarthritis (OA) of the knee. Osteoarthr Cartil. 2013;21(8):1035-1041. doi: 10.1016/j.joca.2013.05.009. 
59. Johnson SA, Figueroa A, Navaei N, et al. Daily blueberry consumption improves blood pressure and arterial stiffness in postmenopausal women with pre- and stage 1-hypertension: A randomized, double-blind, placebo-controlled clinical trial. J Acad Nutr Diet. 2015;115(3):369-377. doi: 10.1016/j.jand.2014.11.001.

6o. Keane KM, Haskell-Ramsay CF, Veasey RC, Howatson G. Montmorency Tart cherries (Prunus cerasus L.) modulate vascular function acutely, in the absence of improvement in cognitive performance. Br J Nutr. 2016;116(11):1935-1944. doi: 10.1017/Sooo7114516004177.

61. Keane KM, George TW, Constantinou CL, Brown MA, Clifford T, Howatson G. Effects of Montmorency tart cherry (Prunus Cerasus L.) consumption on vascular function in men with early hypertension. Am J Clin Nutr. 2016;103(6):1531-1539. doi: 10.3945/ajcn.115.123869.

62. Kent K, Charlton KE, Roodenrys S, et al. Consumption of anthocyanin-rich cherry juice for 12 weeks improves memory and cognition in older adults with mild-to-moderate dementia. Eur J Nutr. 2017;56(1):333-341. doi: 10.1007/s00394-015-1083-y

63. Kent K, Charlton KE, Jenner A, Roodenrys S. Acute reduction in blood pressure following consumption of anthocyanin-rich cherry juice may be dose-interval dependant: A pilot cross-over study. Int J Food Sci Nutr. 2016;67(1):47-52. doi: 10.3109/09637486.2015.1121472.

64. Pigeon WR, Carr M, Gorman C, Perlis ML. Effects of a tart cherry juice beverage on the sleep of older adults with insomnia: A pilot study. J Med Food. 2010;13(3):579-583.doi: 10.1089=jmf.2009.0096.

65. Howatson G, Bell PG, Tallent J, Middleton B, McHugh MP, Ellis J. Effect of tart cherry juice (Prunus cerasus) on melatonin levels and enhanced sleep quality. Eur J Nutr. 2012;51:909-916. doi: 10.1007/s00394-011-0263-7. 
66. Garrido M, Gonzalez-Gomez D, Lozano M, Barriga C, Paredes SD, Rodriguez AB. A Jerte valley cherry product provides beneficial effects on sleep quality. Influence on aging. $J$ Nutr Heal Aging . 2013;17(6):553-560. doi: 10.1007/s12603-013-0029-4.

67. Garrido M, Espino J, Ganzalez-Gomez D, et al. The consumption of a Jerte valley cherry product in humans enhances mood, and increases $5^{-}$ hydroxyindoleacetic acid but reduces cortisol levels in urine. Exp Gerontol. 2012;47(8):573-580. doi: 10.1016/j.exger.2012.05.003.

68. Caldwell K, Charlton KE, Roodenrys S, Jenner A. Anthocyanin-rich cherry juice does not improve acute cognitive performance on RAVLT. Nutr Neurosci. 2016;19(9):423-424. doi: 10.1179/1476830515Y.ooooooooo5.

69. World Health Organisation. Obesity rate.

https://www.indexmundi.com/g/g.aspx?c=tu\&v=2228. Yayınlanma tarihi 2016. Erişim tarihi 23 Mart 2020.

70. Basu A, Betts NM, Nguyen A, Newman ED, Fu D, Lyons TJ. Freeze-dried strawberries lower serum cholesterol and lipid peroxidation in adults with abdominal adiposity and elevated serum lipids. $J$ Nutr. 2014;144(6):830-837. doi: 10.3945/jn.113.188169.

71. Edirisinghe I, Burton-Freeman B. Anti-diabetic actions of berry polyphenols review on proposed mechanisms of action. $J$ Berry Res. 2016;6(2):237-250. doi: 10.3233/JBR-160137. 